\title{
An Early Gravettian cultural attribution for the human fossils from the Cro-Magnon rock shelter (Les Eyzies-de-Tayac, Dordogne)
}

Attribution culturelle au Gravettien ancien des fossiles humains de l'abri CroMagnon (Les Eyzies-de-Tayac, Dordogne, France)

Dominique Henry-Gambier, Roland Nespoulet and Laurent Chiotti

\section{OpenEdition}

\section{Journals}

\section{Electronic version}

URL: http://journals.openedition.org/paleo/2859

DOI: $10.4000 /$ paleo.2859

ISSN: 2101-0420

\section{Publisher}

SAMRA

\section{Printed version}

Date of publication: 15 December 2013

Number of pages: 121-138

ISSN: 1145-3370

\section{Electronic reference}

Dominique Henry-Gambier, Roland Nespoulet and Laurent Chiotti, « An Early Gravettian cultural attribution for the human fossils from the Cro-Magnon rock shelter (Les Eyzies-de-Tayac, Dordogne) », PALEO [Online], 24 | 2013, Online since 04 September 2015, connection on 07 July 2020. URL : http:// journals.openedition.org/paleo/2859; DOI : https://doi.org/10.4000/paleo.2859

This text was automatically generated on 7 July 2020 . 


\section{An Early Gravettian cultural attribution for the human fossils from the Cro-Magnon rock shelter (Les Eyzies-de-Tayac, Dordogne)}

Attribution culturelle au Gravettien ancien des fossiles humains de l'abri CroMagnon (Les Eyzies-de-Tayac, Dordogne, France)

Dominique Henry-Gambier, Roland Nespoulet and Laurent Chiotti

We thank Mr. J.-J. Cleyet-Merle, director of the Musée national de Préhistoire who kindly gave us permission to use the Museum library and J. Angot-Westin for her availability, C. Gaillard for her hospitality at the Prehistory laboratory of the Muséum national d'Histoire naturelle, as well as all of our colleagues, some of whom are specialized in working hard animal matter, who helped us to write up this article.

We also wish to thank C. Letourneux and C. Hoare for proofreading and M. O' Farell who translated some of the English.

\section{1 - Introduction}

In 2002, the $14 \mathrm{C}$ dating by AMS of a perforated shell (Littorina littorea) associated with the skeletons discovered in the Cro-Magnon rock shelter (Lartet 1868) yielded a younger age for these fossils, which had been attributed to the early Aurignacian for a long time (Henry-Gambier 2002). This date indicated that the top of the archaeological sequence of the Cro-Magnon rock shelter contained recent Aurignacian and/or Gravettian layers, after the early Aurignacian, a hypothesis that Breuil (1907, 1909 and 1960), D. de Sonneville-Bordes (1959 and 1960), E. Pittard (1962) and J. Bouchud (1966) had envisaged on the basis of the material collected by several researchers or amateurs, under or around the sepulchral zone at the end of the $19^{\text {th }}$ and the beginning of the $20^{\text {th }}$ century. The date of this shell, Beta 157439: $27680 \pm 270 \mathrm{BP}$, or 31 324-32 666 cal., BP4, 
either corresponds to an interval coinciding witha recent or even a final phase of the Aurignacian, or to an early phase of the early Gravettian (Henry-Gambier 2002). Either way, it rules out an attribution to the early Aurignacian, which corresponds to an earlier period of time in Europe (Zilhão and d'Errico 1999 and 2003; Szmidt et al. 2010; Higham et al. 2011; Joris and Street 2008; Conard and Bolus 2003). The condition of the shell indicates that it had been abandoned on a beach shortly beforehand by the undertow, which undermines the hypothesis that shells dated to 27 to $28000 \mathrm{BP}$ were gathered by much more recent human groups. This conservation status characterizes all the littorinae in the collections of the Muséum national d'histoire naturelle (Paris), the Musée d'Archéologie nationale (Saint-Germain-en- Laye), the Musée d'Aquitaine (Bordeaux), the Muséum d'histoire naturelle (Toulouse) and the Musée du Périgord (Périgueux). This observation would tend to suggest that the Cro-Magnon skeletons are no older than $28220 \mathrm{BP}^{5}$.

2 Although this conclusion was challenged by P. Mellars (2004), it was coherent with the position of the human bones at the top of the infilling, well above the complex attributed to the early Aurignacian. Moreover, the examination of the still accessible lithic material did not bring to light elements from the end of the Upper Palaeolithic or more recent periods ${ }^{6}$. The existence of three pendants in mammoth ivory found beside the human bones with similar characteristics (cf. infra) to other Gravettian funerary ornaments had led one of us to opt for an early Gravettian attribution (Henry-Gambier 2002 and 2008). However, it remained difficult to definitively rule out the hypothesis that the human remains from the Cro-Magnon rock shelter were contemporaneous with a recent phase of the Aurignacian, as there are very few references to Aurignacian funerary practices in Europe.

3 A reexamination of the Gravettian sequence of the Pataud rock shelter, located less than $300 \mathrm{~m}$ downstream of the Cro-Magnon rock shelter (and on the same bank of the Vézère River), of the new Gravettian $14 \mathrm{C}$ dates (Higham et al. 2011) and the Gravettian ornaments indicates that the Cro-Magnon fossils belong to the early Gravettian (fig. 1).

Figure 1 - Cretaceous cliff on the Vézére left bank: localisation of Cro-Magnon and Pataud rock shelters (Photography D. Henry-Gambier).

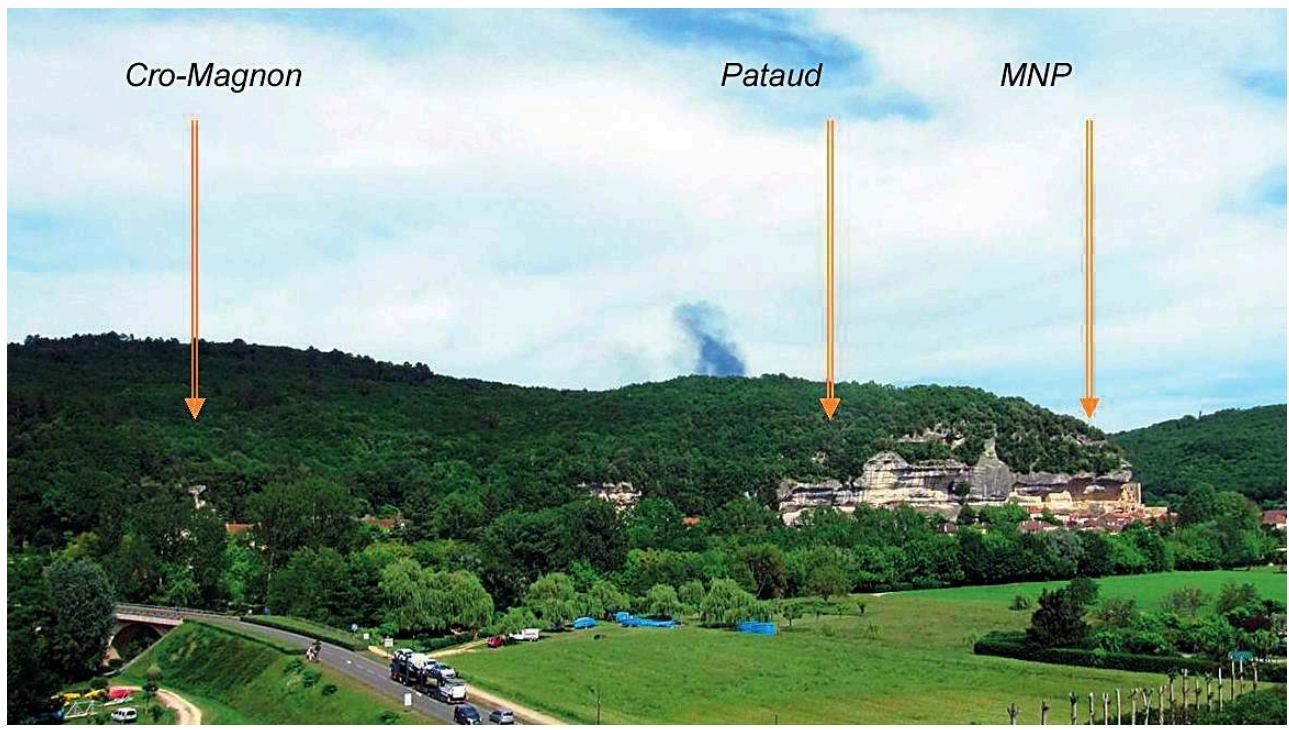




\section{2 - The stratigraphic data}

\section{1 - The sequence from the Cro-Magnon Rock shelter}

4 Less than fifty years after the discovery of the Cro-Magnon rock shelter in March 1868, the site was empty ${ }^{7}$. E. Massénat spent time there in 1868 after L. Lartet, then again in 1872-1873. On September 8 1872, L. Lartet and P. Broca escorted the AFAS congress to visit the site during a meeting in Bordeaux and they proceeded to enhance their collections (Cartailhac1872). In 1893 and 1897, E. Rivière excavated at Cro-Magnon with G. Berthoumeyrou, the owner of the site. H. Breuil carried out some of his earliest field research there in 1897 and 1898 then, in 1905, undertook new excavations with D. Peyrony. Towards 1906-1907, M. Pestourié, G. Berthoumeyrou, lieutenant Bourlon, Dr. Raymond and L. Giraux conducted sporadic fieldwork. F. Leyssale, the owner of the "hôtel de la Gare" (which was to become the future Cro-Magnon hôtel), also collected material from the site. Succinct publications relate these interventions, which generally concern the sepulchral zone along and in front of the cliff (Massénat 1869 and 1877; Rivière 1894, 1897 and 1905; Girod 1906; Peyrony 1907; Breuil 1907 and 1909). No plan or stratigraphic sectiion - or other usable document - of these excavations or gatherings was published. The most comprehensive and rigorous information for the Cro-Magnon site is that of L. Lartet (1868).

5 L. Lartet intervened several days after the human bones were removed under the leadership of A. Laganne, E. Lartet's early foreman, at which stage only the lower complex was preserved in the zone where the skeletons were discovered. The observations concerning the upper part of the sequence were thus made on either side of the sepulchral zone, where the levels were still intact.

6 The rock shelter was completely filled in when it was discovered and contained a 4 to 5 $m$ thick infill. L. Lartet (1868) identified 11 levels (from the base to the top: A to K). According to his description and the sections, two complexes can be distinguished (fig. 2):

- a 2 to $3 \mathrm{~m}$ thick lower complex (A to $\mathrm{H}$ ) with abundant anthropogenic remains, made up of alternating sterile levels of scree (A, C, E) and rather well-defined anthropogenic levels (B, D, $F, G, H)$, which attest to episodes of human occupation and phases of abandon of the rock shelter;

- an upper complex (I, J, K) 1 to $1.5 \mathrm{~m}$ thick, with sparse faunal remains and industries, separated from the lower complex by a series of limestone slabs resulting from the collapse of the rock shelter vault. Layer J, a thin, relatively limited charcoal lens, contained washed and incrusted stalagmite elements. The human remains were lying at the back of the rock shelter, just under the vault, at the base of the upper complex (level I). They were partly exposed (Lartet 1868; Jaubert 1868). The human remains were thus deposited after the deposition of level $\mathrm{H}$ and before that of level $\mathrm{K}$, the last episode of infilling of the shelter, and were thus synchronous with the last occupation of the rock shelter. In 1868, L. Lartet attributed the lower complex to the "Aurignac epoch", defined by E. Lartet (1861), and later extended this conclusion to the upper complex and consequently to the human remains.

7 Today, the analysis of the human bones curated at the Muséum national d'histoire naturelle enables us to confirm some of these early observations, and particularly the position of the remains at the top of the infilling beneath the vault: the presence of ancient fractures on dry bone is compatible with the hypothesis of rather exposed 
bones and the concretions covering the skull (no 4253) and the coxal bones $\left(n^{\circ} 4314\right)$ of Cro-Magnon 1 (fig. 3 and 4), for example, are in keeping with the hypothesis of partially covered bones subjected to water flow, like for certain elements in layer J (see supra). This indicates that the bodies were not buried and that this is therefore not a burial (Henry-Gambier 2008, 2013; Henry-Gambier et al. 2013).

However, the conditions of the discovery of the skeletons, the fact that L. Lartet was not present during the removal of the remains, the speed and methods of the excavation, as well as the conception of prehistoric cultures which pervaded L. Lartet's interpretation at that time mean that we cannot endorse his conclusions concerning the attribution of the sepulchral level to the Aurignac period according to the terminology of that period.

Due to the loss and the mixing up of part of the collections issued from the diverse excavations, it is impossible to conduct a complete restitution of the cultural sequence. However, based on publications (Lartet 1868; Jones 1865-1875; Bourlon 1907; Girod 1906 and 1907; Peyrony 1907; Breuil 1907, 1912) and the material curated in different museums, it is possible to establish the main framework of the sequence, with a certain degree confidence.

10 The base of the sequence included the early Aurignacian with points with split bases, as shown by the material from the L. Lartet collections (Lartet 1868; Jones 1865-1875). The early Aurignacian was also identified in the remains of the E. Rivière, H. Breuil and D. Peyrony excavations, corresponding to levels B and G (Rivière 1897; Peyrony1907; Breuil 1907 and 1909). Above this was one or several recent Aurignacian levels, as shown by the nosed burins and the nosed scrapers in the Bourlon collection in the Institut de Paléontologie Humaine (Sonneville-Bordes 1959 and 1960), a collection which was partly issued from the excavation of level $\mathrm{H}$ by G. Berthoumeyrou (Movius 1969). A nosed burin also exists in the small series of the L. Lartet collection in the Muséum d'histoire naturelle in Toulouse (F. Bon, pers. com.). 
Figure 2 - Cro-Magnon rock shelter: Stratigraphy (drawing D. Henry-Gambier according to Lartet 1868; Lartet and Christy 1865-1875).

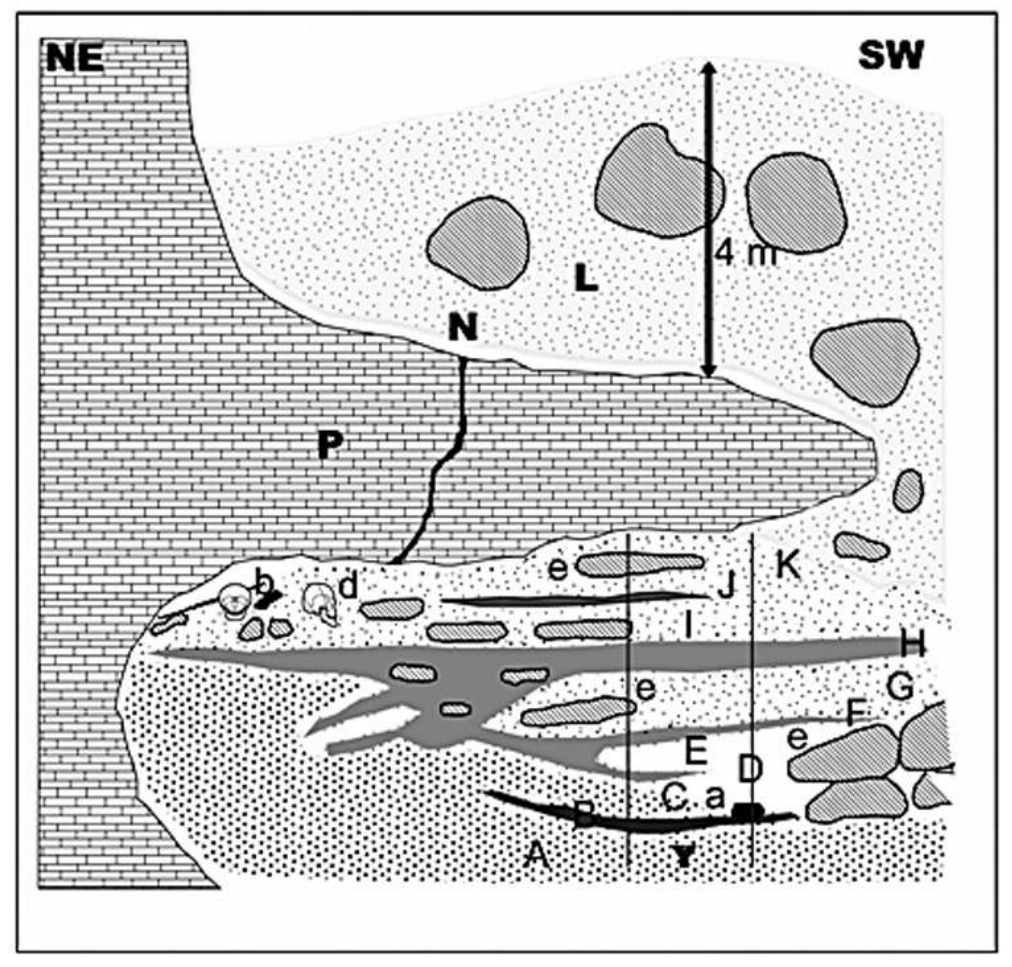

A. Limestone debris; B. first layer of ashes, etc.; C. limestone debris; D. second layer of ashes, etc; E. Limestone debris reddened by fire under the next layer of ashes, etc; F. third layer of ashes; G. red earth, with bones etc; $\mathrm{H}$. thick layer of ashes with bones (main hearth); I. yellowish earth, with bones, etc; $J$. thin bed of washed gravels incrusted with stalagmites. Faint hearth traces; K. Limestone scree; L. Removed talus; N. Crack in the shelter roof; P. Projecting ledge of Cretaceous limestone forming the roof of the shelter; Y. Pillar made to support the roof; a. elephant tusk; $b$. bones from an elderly skeleton; c. block of gneiss flattened on one side; $d$. human bones; e. limestone slabs fallen from the roof at different times (Legend according to Lartet 1868 - p. 342; Lartet and Christy 1865-1875 - p. 67).

11 The top of the infilling contained Gravettian remains, represented by a series of Gravette points from the Rivière collection at the Latenium Museum (Pittard 1962 and Bouchud 1966). A possible Gravette point (CMA 9925 29) and a Bayac fléchette (CMA 99 25 29), issued from a series of pieces from the E. Cartailhac collection from the Muséum d'histoire naturelle in Toulouse (Delluc and Delluc 2013) would tend to confirm this Gravettian presence. However, the exact context of these two pieces and their relation to the material found at Cro-Magnon remain, in our opinion, difficult to prove. Moreover, two engraved bones of Gravettian workmanship, representing a human and a bison, were also found in this level (Breuil 1907, 1960). These engravings were found in the rock shelter by G. Berthoumeyrou in or around 1897 on the far left side of the site (Breuil 1960), and now belong respectively to the collections of the Périgord Museum, in Périgueux, and the Latenium Museum (Pittard 1962; Féaux 1902). H. Breuil drew these pieces in 1900 and compared them to engravings from level III with Gravette points from the Trilobite Cave, in Arcy-sur-Cure (Breuil 1907, 1960). Lastly, the $14 \mathrm{C}$ littorina date (Henry-Gambier 2002) provides additional evidence of Gravettian presence.

In the context of the "Aurignacian battle", the existence of the Solutrean at CroMagnon was very controversial (Breuil 1907, 1909, 1912 and 1960; Massénat 1869 and 
1877; Massénat and Girod 1893; Girod 1906 and 1907). The E. Massénat collection (MAN), and the L. Lartet collection (Muséum d'histoire naturelle de Toulouse), contain a series of Solutrean lithic pieces (Smith 1966; Pelegrin and Bon pers. com.), which can, according to P.E. Smith (1966 - p. 159), be attributed to the Middle Solutrean. H. Breuil (1909) finally acknowledged a Solutrean presence at Cro-Magnon and the presence of a small Solutrean "hearth", at the front of the rock shelter. On the other hand, neither the texts, nor the published figures (Lartet and Christy 1865-1875), nor the analysis of the lithic collections point to occupations after the Solutrean (Pelegrin and Bon, pers. Com.).This sequence with early and recent Aurignacian remains, Gravettian and probably some Solutrean elements, evokes the Pataud rock shelter sequence (Movius 1975, 1977; Bricker 1995). However, it is important to underline that the respective amplitude of the represented cultural phases seems to have been different at both sites.

Figure 3- Cro-Magnon rock shelter. coxal bone n o 4314 with calcite deposit (Collection MNHN, Photograph 0. Henry-Gambier).

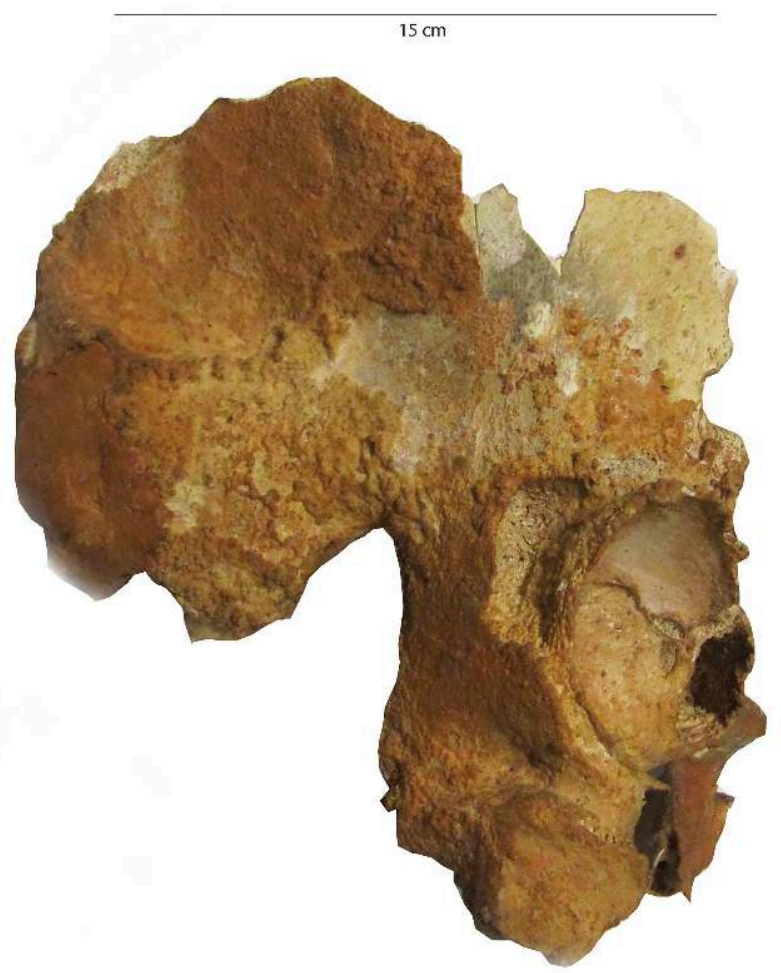


Figure 4 - Cro-Magnon rock shelter. Skull $n^{\circ} 4253$ with calcite deposit (Collection MNHN, Photograph D. Henry-Gambier).

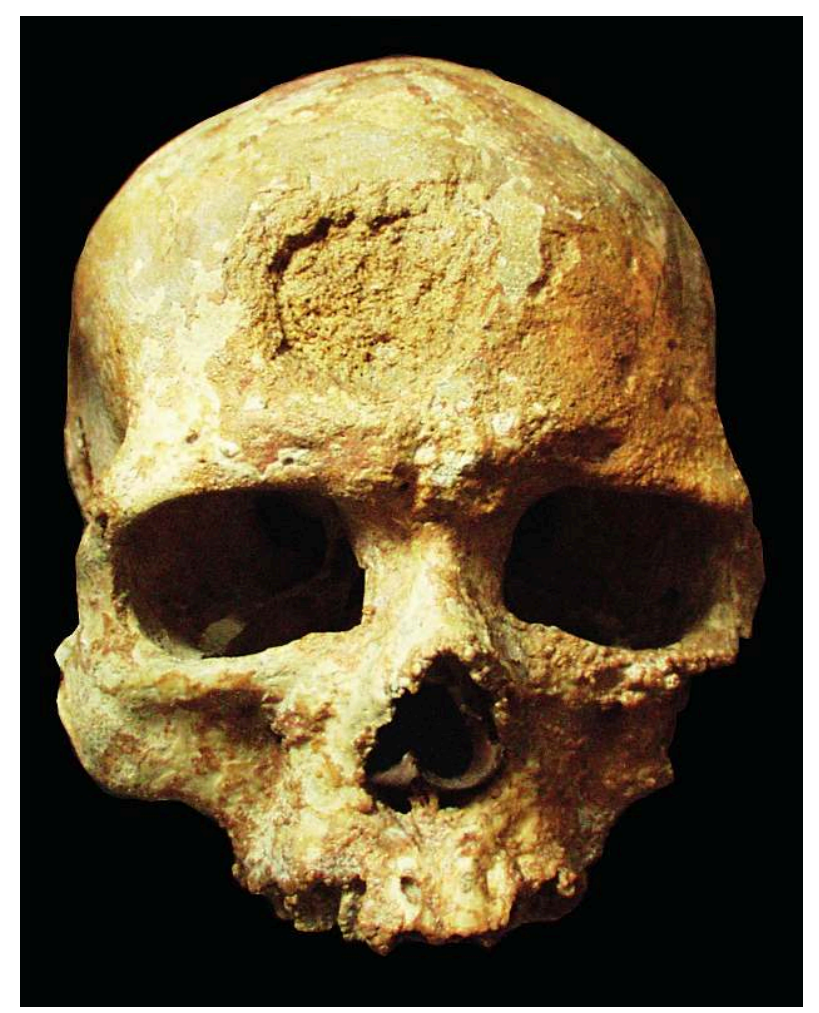

\section{2 - The Pataud rock shelter sequence} attains a thickness of $9 \mathrm{~m}$. It is thus much more substantial than that of Cro-Magnon The archaeostratigraphy is made up of fourteen archaeological levels separated by sterile scree (Movius 1977) and comprises one of the most complete early Upper Palaeolithiic sequences in Europe, extending from the early Aurignacian to the Solutrean (fig. 5). allotted to the early Aurignacian (C14 to C9) and the recent Aurignacian (C8 to 6; Chiotti 2005). The Gravettian contains four layers attributed to the early (C5), middle (C4) recent (C3) and final (C2) Gravettian. The thickness and the abundant archaeological material in these layers indicate significant occupations (Movius 1977; Bricker 1995; Nespoulet et al. 2008). The Solutrean layer (C1) is associated with an early phase of this culture, and contains little material, which has been subjected to severe disturbance. Laurel leaf points from the middle Solutrean were also present outside the main excavation zone, on top of the talus (Nespoulet 1993).

The recent review of the geology and the sedimentogenesis of the site (Agsous 2008; Lenoble and Agsous 2012), based on the north and south sections, led to the identification of eight lithostratigraphic units formed of one or several lithofacies (from the top to the bottom: I to VIII).

16 The early Aurignacian is in unit VII, the recent Aurignacian in units VII and VI. Unit VII is a well-stratified scree facies resulting from the progression of stone-banked 
solifluction slides whereas unit VI is a massive deposit made up of blocks, heterometric stones and limestone slabs corresponding to scree gravity accumulation.

The early Gravettian and the middle Gravettian are in unit V, the recent and final Gravettian in unit III (Agsous 2008; Lenoble and Agsous 2012). Unit IV contains little material and corresponds to run-off and processes of gravity accumulation. Unit V is a massive deposit with a matrix corresponding to a solifluction deposit beneath grass. In unit III, the recent Gravettian is present in deposits accumulated by gravity towards the exterior of the shelter and solifluction beneath grass towards the interior whereas the final Gravettian is in stone-banked solifluction deposits and cryoturbated deposits.

Whatever the syn and post-depostional phenomena identified at the site, the sedimentary inputs almost always come from the surrounding limestone by scree phenomena (repeated collapse of small volumes of rocks) and collapse (caving in of the shelter roof).

\section{3 - Cro-Magnon and Pataud}

Data from the two infillings are very disparate as the two sites were studied almost 150 years apart but they nonetheless confirm the existence of common points between the two sites.

201 - The major role of processes of gravity (scree and rock shelter roof collapse) in the formation of the infilling. L. Lartet (1868) described "sterile scree" between occupation episodes and collapsed slabs from the shelter roof at different levels of the stratigraphy. The infill from the Cro-Magnon rock shelter thus formed in a similar palaeoenvironmental context to that of the Pataud rock shelter and probably presented the same morpho-sedimentary system. If the sedimentological information from the top of the Cro-Magnon stratigraphy (I, J and $\mathrm{K}$ ) is not sufficient to define the correlation between the sepulchral level from Cro-Magnon and one of the Pataud levels, it is nonetheless evocative of the characteristics described for the lithostratigraphic complexes V and IV of the Pataud rock shelter (Agsous 2008; Lenoble and Agsous 2012).

2 - Early and recent Aurignacian occupations as well as Gravettian and Solutrean presence. The Cro-Magnon rock shelter was practically filled at the end of the Aurignacian and therefore the Gravettian sequence could not have attained the same proportions as at the Pataud rock shelter. Moreover, no elements point towards middle Gravettian occupations at Cro-Magnon, (Noailles burins are absent), nor to recent or final Gravettian episodes. Only the early Gravettian appears to have been present. Although it is impossible to rule out the hypothesis of an early Gravettian occupation at the front of the shelter, the scant diagnostic material in the Cro-Magnon series does not point to long and intensive occupations, but rather to sporadic visits. Conversely, it is worth mentioning the 1789 Gravette points from layer 5 of the Pataud rock shelter (typical points, atypical points and microgravettes) (Leoz 2007). It is more than likely that an occupation of comparable intensity at Cro-Magnon would have led to a much more widespread, albeit biased, collection of Gravettian material than that suggested by the material which survived loss and destruction linked to excavations or the hazards of curation since 1868. It is noteworthy that the elements illustrated by $\mathrm{H}$. Christy and E. Lartet (1865-1875) are Aurignacian and correspond to the excavation of the lower levels. 
Finally, in both rock shelters, the Solutrean occupations took place when the shelter was practically totally filled in and the roof had collapsed, except, perhaps in the Movius shelter, located to the south of the Pataud rock shelter ${ }^{8}$.

Figure 5 - Pataud rock shelter. Stratigraphic section (Drawing C. Lecante and L. Chiotti).

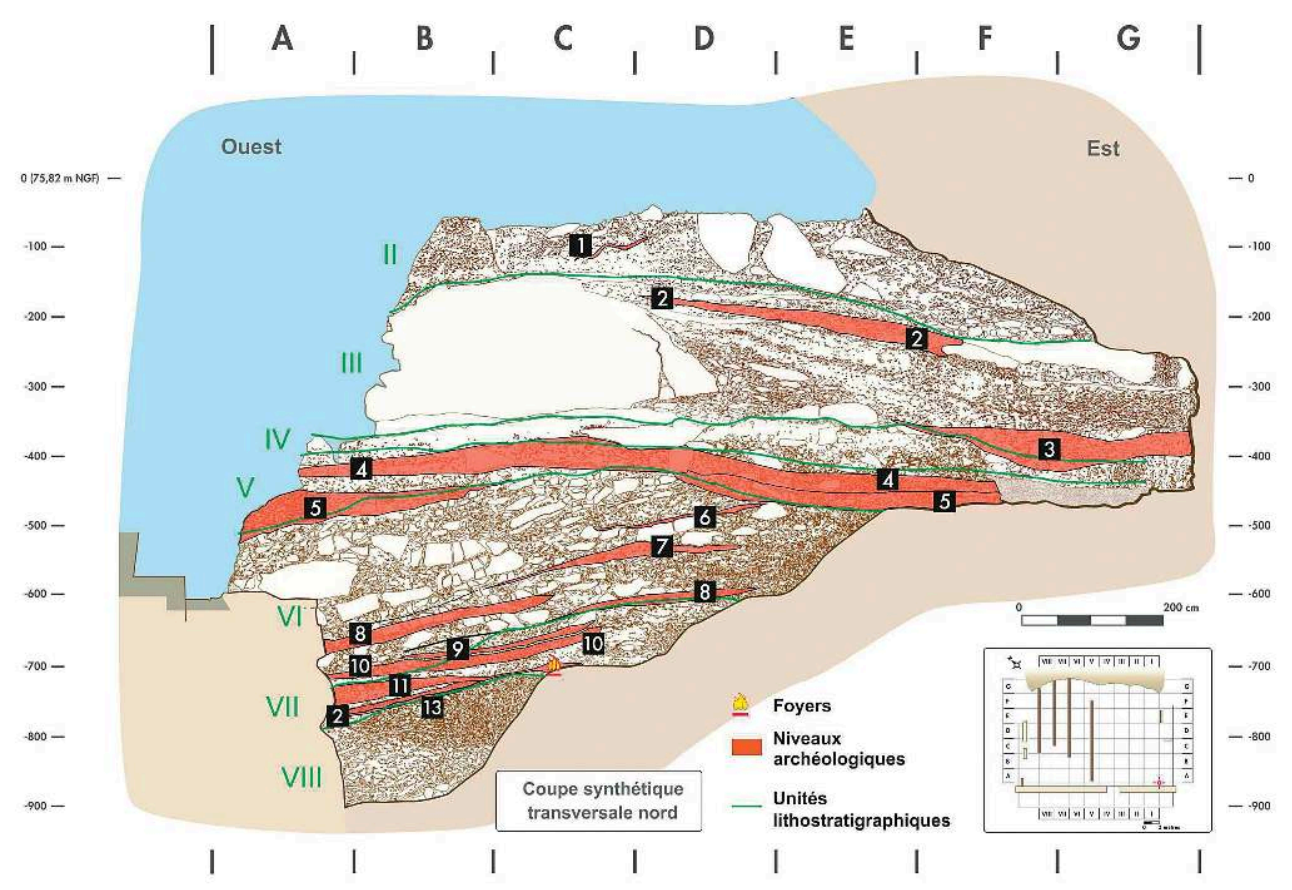

\section{3 - Dating}

L. Lartet (1868) considered that the bones were at the base of layer I, which was clearly separated from layer $\mathrm{H}$, which he excavated when he first arrived at the site, by a collapsed level (fig. 2). According to H.L. Movius (1969), the burial was from level H, which was acknowledged as synchronous with level 6 of Pataud, the ultimate phase of the Aurignacian sequence. Based on the $14 \mathrm{C}$ date of $32800 \mathrm{BP} \pm 450$ (GrN-3117) for level 7 of the Pataud rock shelter, he evaluated the age of the overlying level 6 , and consequently, that of the sepulchral level in the Cro-Magnon rock shelter, at $30000 \mathrm{BP}$.

The comparison of the date (Beta 157439: $27680 \pm 270 \mathrm{BP}$, or $31324-32666 \mathrm{cal} \mathrm{BP}$ ) of the perforated littorina from Cro-Magnon with the results of the first series of $14 \mathrm{C}$ dates from the Pataud rock shelter sequence (Bricker 1995) invalidates the correlation of the sepulchral level of the Cro-Magnon rock shelter with level 6 (recent Aurignacian) from the Pataud rock shelter. It suggests, on the other hand, a correlation with level 4 (middle Gravettian) or level 5 (early Gravettian). The new dates (Higham et al. 2011) from the Aurignacian sequence and the beginning of the Gravettian at the Pataud rock shelter confirm that the Cro-Magnon littorina is much more recent than level 6 (tab. 1). The date fits into the intervals of the four earliest dates for level 5. According to T. Higham and his collaborators, the results for the Pataud rock shelter point towards a hiatus of 1850 to 3250 years between the last Aurignacian occupation and the early Gravettian. If this date was confirmed, the perforated littorina from Cro-Magnon would not be of Aurignacian age. 
Table 1 - Pataud level 5 and $6 \mathrm{C} 14$ datations (from Higham et al. 2011). CALIB version 6.0 intcal09.14C (Reimer et al. 2009).

\begin{tabular}{|c|c|c|c|}
\hline $\begin{array}{c}\text { Référence } \\
\text { laboratoire }\end{array}$ & Site et couche & $\begin{array}{c}\text { Date BP } \\
\text { conventionnelle }\end{array}$ & $\begin{array}{c}\text { Date calibrée } B P \\
\text { à 2 sigma }\end{array}$ \\
\hline $2225-38$ & Abri Pataud couche 5 & $26780 \pm 280$ & $30895-31545(p=1)$ \\
\hline 21587 & Abri Pataud couche 5 & $28150 \pm 290$ & $31575-33173(p=1)$ \\
\hline 21585 & Abri Pataud couche 5 & $28180 \pm 270$ & $31613-33176(p=1)$ \\
\hline 21586 & Abri Pataud couche 5 & $28230 \pm 290$ & $31620-33257(p=1)$ \\
\hline 21588 & Abri Pataud couche 5 & $28250 \pm 280$ & $31646-33264(p=1)$ \\
\hline 21681 & Abri Pataud couche 6 & $31200 \pm 400$ & $34955-36515(p=1)$ \\
\hline
\end{tabular}

\section{4 - Data from the ornaments}

\section{1 - The pendants from the Cro-Magnon rock shelter}

When the rock shelter was discovered, three ivory pendants were found in the immediate vicinity of the skeletons (Lartet $1868-$ p. 12-13). They are illustrated in the Reliquae Aquitanae (Lartet and Christy 1865-1875 - PL XI). Two of them are kept in the Prehistory laboratory in the Muséum national d'histoire naturelle and the third has disappeared.

\section{First pendant, piece $n^{\circ} 48-18-581$}

The pendant $\mathrm{n}^{\circ} 48-18-581$ is oval $(31.5 \mathrm{~mm} ; 23 \mathrm{~mm})$ and has a flat section (thickness 4.9 $\mathrm{mm})$. It is slightly asymmetric, as one of the edges is more convex than the other. One end of the pendant bears two perforations of equal diameter $(2.9 \mathrm{~mm}), 3.3 \mathrm{~mm}$ apart (fig. 6 and tab. 2). The irregular fracture above the two perforations presents a blunted and slightly concretionary facet which attests to its age and reveals the internal structure of the ivory. Some gaps can be observed in the centre of both sides of the piece, due to scaling and/or post-depositional alteration of the ivory (one of these has been partially filled with plaster), as well as vermiculations. The edges are chipped in several places and are characterized by progressive thinning, giving them a bulging profile. It is possible to make out scraping traces extending from the lateral side nearest the perforations to the opposite end. These marks precede the perforations, which cut into them, and indicate an early shaping phase of the pendant. Many other finer striations, clustered together with no preferential orientation indicate a phase of very careful abrasion. Sheen also covers both sides of the pendant. The perforation has a bi-conical section and was made from both sides of the piece, probably by semirotating scraping. The perforated sides are smooth and no striations resulting from the action of the flint tool are visible. This smoothness could be due to the repeated rubbing of a cord through the hole, which would indicate the prolonged use of the pendant. In this case, it is difficult to identify how the pendant was worn (if it was hung or attached to something). 
Table 2 - Cro-Magnon et Pataud (Dordogne) - Dimensions and characteristics of perforations pendants $(\mathrm{H}=$ height, Larg. = width, Ép. = thickness, max. = maximum, prox. = proximal $)$.

\begin{tabular}{|c|c|c|c|c|c|c|c|}
\hline $\mathrm{N}^{\circ}$ objet & $\begin{array}{l}\text { État de } \\
\text { conservation }\end{array}$ & $\begin{array}{c}\text { Haut.max. } \\
\mathrm{mm}\end{array}$ & $\begin{array}{l}\text { Larg. max. } \\
\text { mm }\end{array}$ & $\begin{array}{c}\text { Ép. max. } \\
\mathrm{mm}\end{array}$ & Ép./H & $\begin{array}{l}\text { Nombre de } \\
\text { perforations }\end{array}$ & État des perforations \\
\hline $\begin{array}{l}\text { AP/61-5- } \\
7898\end{array}$ & \begin{tabular}{|l|} 
Région ou \\
partie \\
proximale \\
manquante
\end{tabular} & 11,1 & 13,0 & 3,6 & 0,3 & 1 & $\begin{array}{l}\text { extrémité proximale } \\
\text { cassée anciennement }\end{array}$ \\
\hline $\begin{array}{c}\text { AP/61-5- } \\
9613\end{array}$ & complète & 11,4 & 11,4 & 3,6 & 0,3 & 1 & complète \\
\hline $\begin{array}{l}\mathrm{AP} / 61-5- \\
6302\end{array}$ & \begin{tabular}{|l} 
région \\
proximale \\
manquante
\end{tabular} & 12,9 & 11,7 & 4,5 & 0,3 & 1 & $\begin{array}{l}\text { totalement endommagée } \\
\text { (non photographiée) }\end{array}$ \\
\hline $\begin{array}{l}\mathrm{AP} / 61-5- \\
6301\end{array}$ & \begin{tabular}{|l|} 
région \\
proximale \\
manquante
\end{tabular} & 13,3 & 13,8 & 4,0 & 0,3 & 1 & $\begin{array}{l}\text { bord supérieur et bord } \\
\text { latéral cassés }\end{array}$ \\
\hline $\begin{array}{l}\mathrm{AP} / 60-5- \\
5411\end{array}$ & \begin{tabular}{|l} 
région \\
proximale \\
manquante
\end{tabular} & 13,3 & 10,0 & 4,9 & 0,4 & 1 & $\begin{array}{l}\text { bord supérieur cassé } \\
\text { anciennement }\end{array}$ \\
\hline $\begin{array}{l}\text { AP/61-5- } \\
6235\end{array}$ & \begin{tabular}{|l|} 
région \\
proximale \\
manquante
\end{tabular} & 14,1 & 10,0 & 3,0 & 0,2 & 1 & $\begin{array}{l}\text { bord supérieur et bord } \\
\text { latéral cassés }\end{array}$ \\
\hline $\begin{array}{l}\text { AP/61-5- } \\
7009\end{array}$ & complète & 15,4 & 10,8 & 4,4 & 0,3 & 1 & complète \\
\hline $\begin{array}{c}\text { AP/59-5- } \\
1806\end{array}$ & complète & 15,7 & 11,8 & 5,4 & 0,3 & 1 & complète \\
\hline $\begin{array}{l}\text { AP/61-5- } \\
6947\end{array}$ & \begin{tabular}{|l|} 
région \\
proximale \\
manquante
\end{tabular} & 16,5 & 12,7 & 3,2 & 0,2 & 1 & $\begin{array}{l}\text { bord supérieur cassé } \\
\text { anciennement }\end{array}$ \\
\hline $\begin{array}{l}\mathrm{AP} / 61-5- \\
8476\end{array}$ & \begin{tabular}{|l|} 
région \\
proximale \\
cassée
\end{tabular} & 17,5 & 13,4 & 3,9 & 0,2 & 1 & $\begin{array}{l}\text { bord supérieur cassé } \\
\text { anciennement }\end{array}$ \\
\hline $\begin{array}{l}\mathrm{AP} / 60-5- \\
2190\end{array}$ & \begin{tabular}{|l|} 
région \\
proximale. \\
manquante
\end{tabular} & 18,9 & 13,8 & 5,1 & 0,3 & 1 & $\begin{array}{l}\text { bord supérieur cassé } \\
\text { anciennement }\end{array}$ \\
\hline $\begin{array}{c}\text { AP/61-5- } \\
7749\end{array}$ & complète & 20,3 & 13,2 & 4 & 0,2 & $\begin{array}{c}\text { non } \\
\text { perforée }\end{array}$ & \\
\hline $\begin{array}{c}\mathrm{CM} 48-18- \\
582\end{array}$ & \begin{tabular}{|l} 
région \\
proximale \\
manquante
\end{tabular} & 16,0 & 13,2 & 4,4 & 0,3 & 1 & $\begin{array}{l}\text { bord supérieur cassé } \\
\text { anciennement }\end{array}$ \\
\hline $\begin{array}{l}\text { CM 48-18- } \\
\quad 581\end{array}$ & \begin{tabular}{|l} 
région \\
proximale \\
manquante
\end{tabular} & 31,5 & 23,0 & 4,9 & 0,2 & 1 & complète \\
\hline
\end{tabular}

Figure 6 - Cro-Magnon rock shelter. pendant $n^{\circ}$ 48-18- 581, sides 1 (a) and 2 (b). (Collection MNHN, Photograph D. Henry-Gambier).

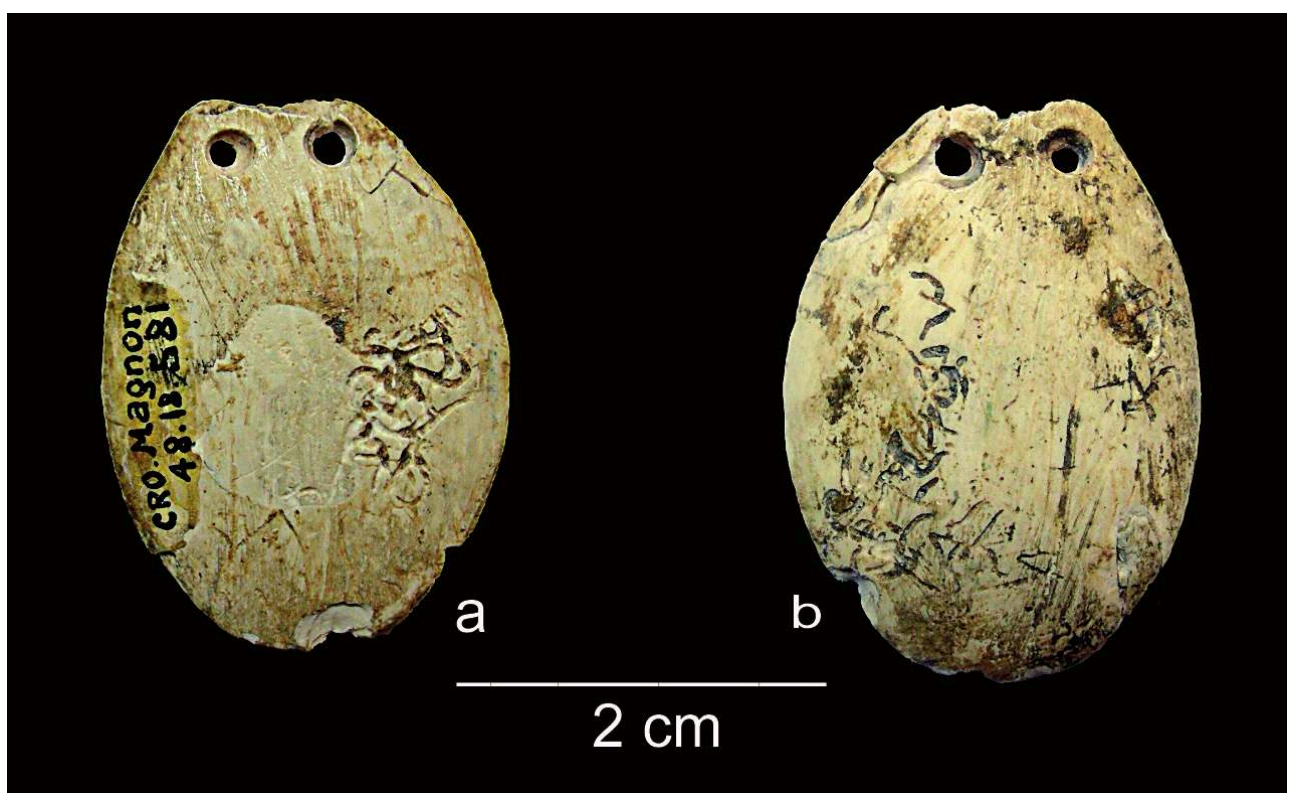

Second pendant, piece $n^{\circ} 48-18-582$

Pendant $\mathrm{n}^{\circ} 48-18-582$ is smaller than the previous piece $(16 \mathrm{~mm} ; 13.2 \mathrm{~mm})$ and proportionally thicker (thickness $4.4 \mathrm{~mm}$ ). It displays more marked asymmetry and a less regular shape. It is broken at the perforation (fig. 7 and tab. 2). The fracture facet is 
white and its aspect suggests relatively recent erosion. The surface of the piece is covered by a thick and shiny film due to the product used for the consolidation process. It is also covered in dark stains, linked to natural degeneration, and ocher dots. The side bearing the inventory number is plane and undoubtedly corresponds to the cleaved surface during the sectioning of the tusk, whereas the other side is more convex. The edges of the pendant are regularly rounded and polished. On both sides, blunting and sheen have erased most traces of scraping and abrasion. Before the perforation stricto senso, a "scraping" phase (Taborin 1993) was applied to both sides to thin the zone to be perforated and to make it easier to grip the surface with a flint tool. Moreover, ocher-covered incisions are still visible under the lower edge of the perforation.

The concretions observed on the first pendant and the ocher colouring the second point towards a close link between these ornaments and the human bones, which are also partly concretionary and covered in ocher.

Figure 7 - Cro-Magnon rock shelter. pendant $n^{\circ} 48-18-582$, faces 1 (a) and 2 (b). Photography $D$. Henry-Gambier, collection Muséum national d'Histoire naturelle).

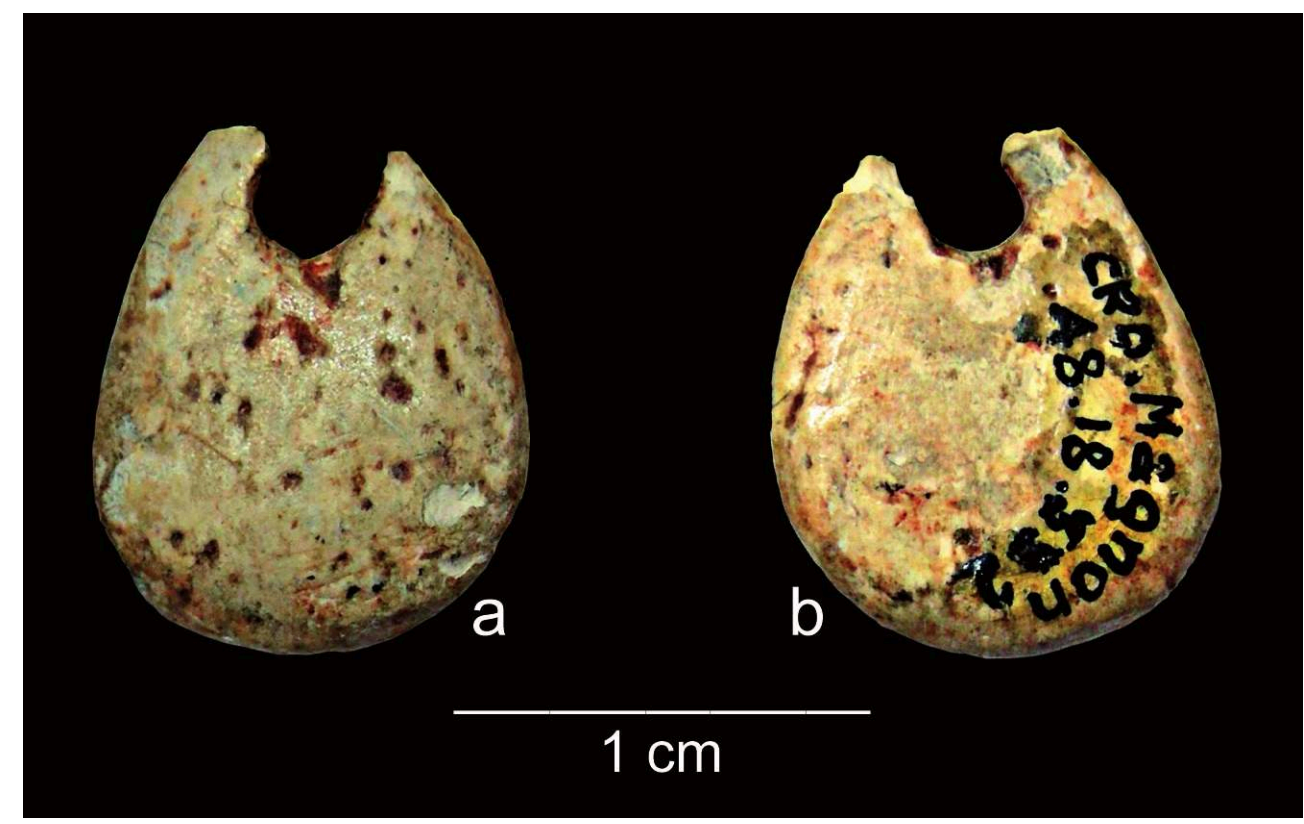

Third pendant, disappeared from the collection

29 The last pendant of the series appears to have been complete, judging by the lithography published by E. Lartet and H. Christy (1865-1875 - PLXI). The size and shape of this piece are very similar to those of the pendant 48-18-582.

\section{2 - The pendants from level 5 of Pataud rock shelter}

30 Level 5 of the Pataud rock shelter yielded twelve ivory pendants (tab. 2) discovered between 1959 and 1961 by H.L. Movius in bands III, IV and V (Vercoutère 2004 and Vercoutère et al. 2008).

31 Four of these are intact, eight present damage in the proximal region. One has not yet been perforated. They are described as pendants shaped like "pumpkin seeds" (Bricker 
1995) or "pumpkin pips", although their dimensions and their shape vary. They are all relatively thin and none of them can be considered as a reproduction of a cervid canine (fig. 8 and 9).

The pendant AP/61-5-9613 is diamond-shaped. The distal end is wider than the proximal end. Pendant AP/61-5-7009 fits into a rectangle, and the distal and proximal sides are slightly convex. The other pendants are characterized by edges converging towards the proximal end. On the other hand, the distal extremity is regularly convex.

The shaping of these pieces is variable and in some cases is incomplete. It was carried out by scraping, which left marks on the edges of most of the pendants. Both sides also bear scraping marks, which vary according to the intensity of abrasion and the sheen which covers the surface. The latter is difficult to define as, in certain cases, it could be due to intentional polishing, whereas in others, it may result from wearing the pendants. Lastly, pendant AP/60-5-5411 is a rough out and shaping was abandoned before the abrasion phase.

On the distal end of pendant AP/61-5-9613, a clear fracture facet suggests that this piece was one of a series made from an elongated blank shaped by scraping (Hahn 1995; Goutas 2004). This is not so clear on the proximal end. This fracture facet is very narrow and discrete and results from the final breaking of the blank by bending. At both ends of the pendant, the presence of incisions perpendicular to the axis of the piece and parallel to each other, attest to cutting by sawing.

The existence of two pendant modules (tab. 2) either implies that they were produced from rods of different modules, or else, for the smaller pendants, that the volume of the rough outs was significantly reduced by additional scraping, as suggested by N. Goutas $(2004,2005)$ for other ornamental elements. Finally, we can also envisage a last hypothesis, whereby this difference in module could result from a repair process of certain elements after the breakage of the perforated zone. The setting up of a new perforation, or a new general shaping of the piece could have led to the progressive reduction of the original volume of the pendants. However, at the present time, no technological argument backs up this latter hypothesis (renewed shaping, rupture of the profile, dissymmetry of the pendants, etc.).

The narrowest part of the rough out was perforated. The piece AP/61-5-7749 was not perforated when shaping had been completed; on the other hand, the perforation of the pendant AP/60-5-5411 seems to have been conducted before the abrasion phase. In most cases, thinning by scraping, which left deep and vertical striations on either side of the perforation, seems to have been carried out to regularize the blank prior to perforation.

The latter was carried out by semi-rotating scraping, apart from for the pendant AP/ 60-5-5411, for which after the thinning phase, the perforation was made by pressure or by light percussion with a pointed tool. It is not possible to distinguish these two techniques (Goutas 2004). Percussion or pressure may also have been used on the other pendants before the rotating scraping and this may have eradicated the marks left by this first stage of perforation preparation.

The scraped zones bear traces of red ocher, as does the rest of the surface, which could result from the use of an abrasive agent. However, the pendant AP/60-5-5411 bears a lot of ocher whereas the abrasion phases had not yet begun. It is thus possible that the ocher present in the sediment might be at least partially responsible for this colouring. 
39 The study of the pendants from level 5 of the Pataud rock shelter suggests an operative schema similar to that described by N. Goutas (2004 and 2005) for the early Gravettian pendants from the site of La Gravette (Dordogne):

- production of an elongated rod-like blank (secondary block);

- general shaping of the blank by scraping;

- cutting of the rod at regular intervals to produce the pendant preforms: transversal sawing and breaking by bending;

- shaping of the preforms by scraping;

- abrasion;

- and possibly, polishing.

The perforation is made either before the abrasion or after the polishing.

Figure 8 - Pataud rock shelter. pendants, side 1 (collection MNHN, photograph L. Chiotti).

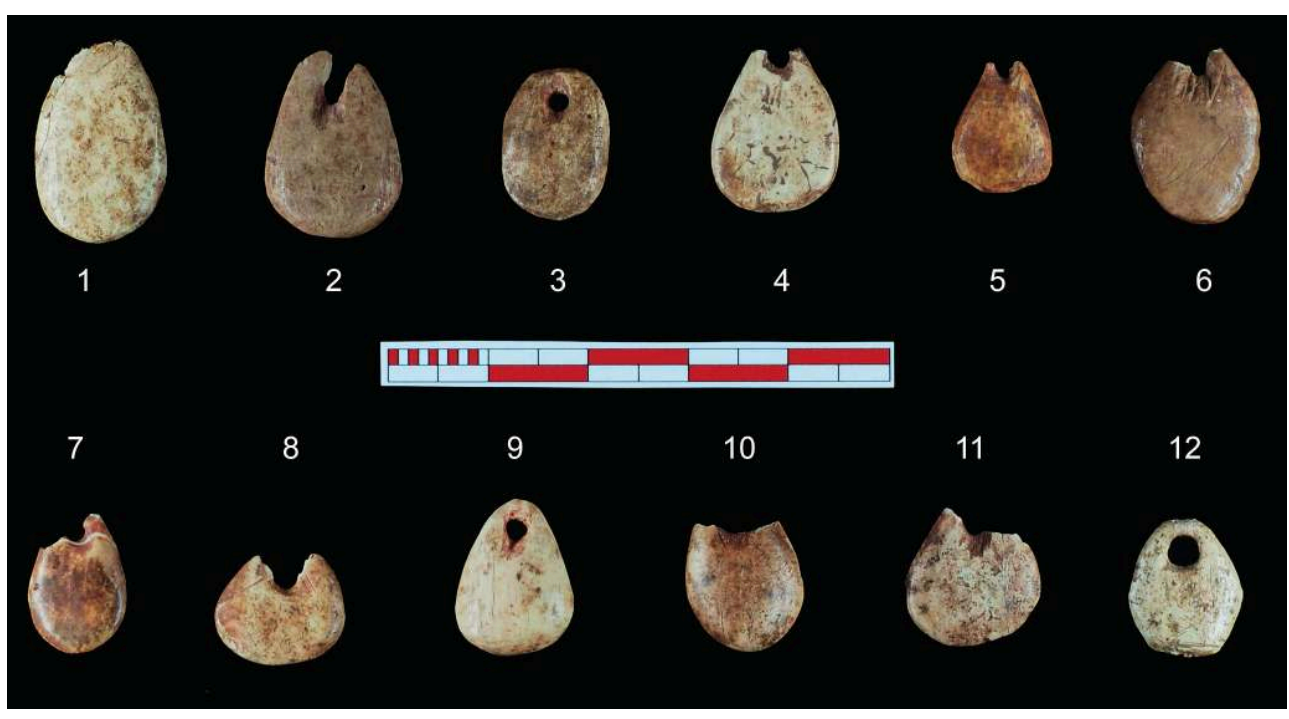

Figure 9 - Pataud rock shelter. pendants, side 2 (collection MNHN, photograph L. Chiotti).

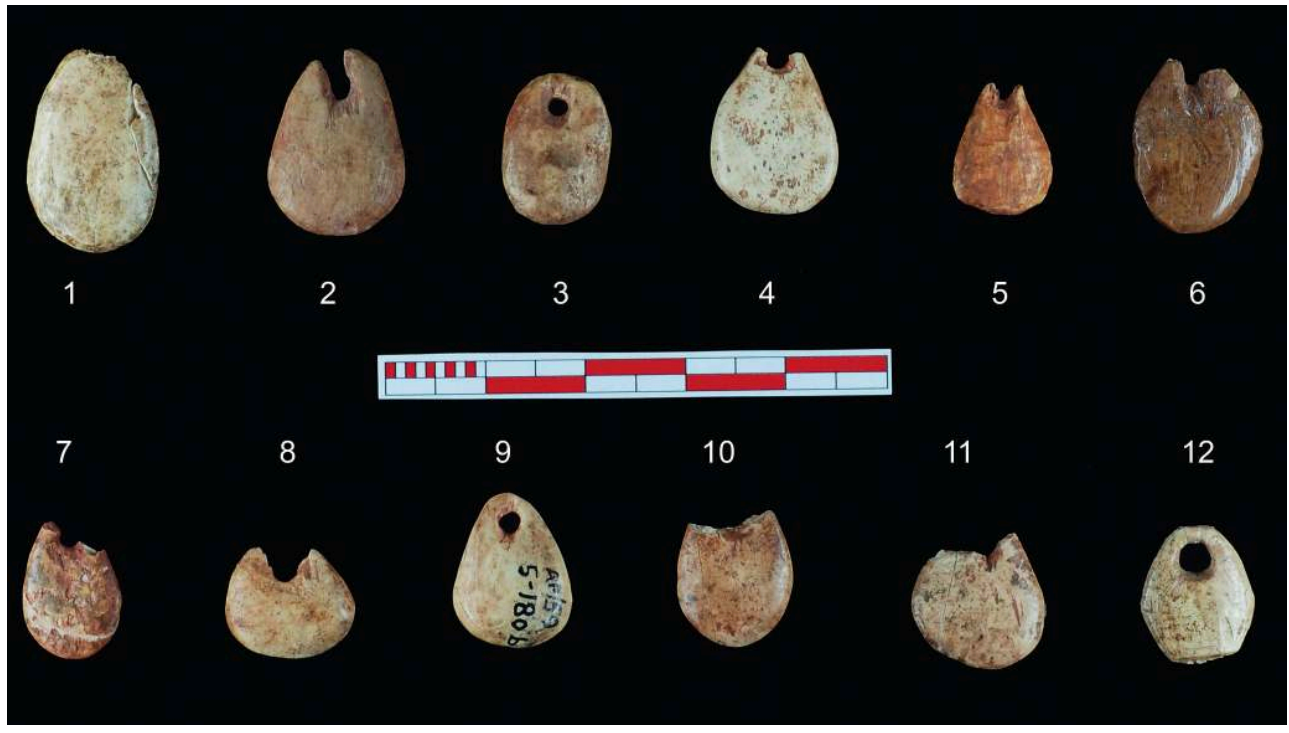




\section{5 - Comparison of the pendants from Cro-Magnon and Pataud}

41 The two ivory pendants from the Cro-Magnon rock shelter present several common features with those from the Pataud rock shelter:

1. the use of an identical raw material, ie., ivory from a mammoth tusk;

2. a similar module, a more or less oval shape and a flat section. The pendant 48-18-581 from Cro- Magnon is very similar to the unfinished pendant AP/61-5-7749 from Pataud; the CroMagnon pendant 48-18-582 fits into the morphological variability of the other pendants from Pataud;

3. the operative schema for shaping the pendant 48-18-582 from Cro-Magnon is identical to that applied to the Pataud pendants. However, for the pendant 48-18-581, a different technique was used for the perforated zone: the two openings were perforated by semirotating bifacial scraping with no visible signs of previous preparation. In Pataud and on the pendant 48-18-581 from Cro-Magnon, all the openings were perforated by bifacial scraping, then by rotating scraping. The perforation of two holes on the pendant 48-18-581 from CroMagnon could perhaps explain this change in technique. Other reasons can also be envisaged, such as production by different artisans.

This similarity between the two rock shelters also concerns the shell ornaments. The dominant species at Cro-Magnon, Littorina littorea, is also present in level 5 at the Pataud rock shelter (Dance 1975), although in smaller quantities. However, at CroMagnon, there is a greater diversity of species, with the presence of: Purpura (nucella) lapillis, Turritella communi and Sipho jeffreysianus, which are Atlantic species; Hinia reticulata, a Mediterranean or fossil species; Trivia europea, an Atlantic or Mediterranean species; fossil Turitella sp., Chlamys sp. and fossil Ostrea. These species are not characteristic of any particular Upper Palaeolithic culture in Western Europe (Fisher 1872; Taborin 1993), but some of them, such as Purpura (nucella) lapillus, Turritella communi and fossil Ostrea, have been identified in the early Gravettian at the site of $\mathrm{La}$ Gravette. Moreover, the manufacturing process for the perforated zones of the shells is identical at all three sites (Taborin 1993), although this argument is only of limited relevance here as shell perforation techniques were very stable during the Upper Palaeolithic.

\section{6 - Discussion, conclusion}

The concomitant review of the ivory pendants from the sepulchral level of the CroMagnon rock shelter and the early Gravettian level 5 from the Pataud rock shelter shows that these ornamental elements have the following features in common; raw material, shape and manufacturing techniques. The specific technique of perforation used for the pendant 48-18-581 from Cro-Magnon could be explained by an adaptation of the perforation process to the desired shape, or to a different method of attaching or hanging the pendant, or even to the intervention of another artisan. This specific example, which is a pendant with two perforations, is an example of "use of varied combinations of techniques for the manufacture of ornaments", observed by N. Goutas (2004 - p. 254) on animal teeth in other Gravettian sites. 

sepulchral level of the Cro-Magnon rock shelter and the early Gravettian level (C5) from the Pataud rock shelter. The age of the perforated littorina, which corresponds to the new $14 \mathrm{C}$ dates from level 5 of the Pataud rock shelter, corroborates this conclusion. pendants from the Gravettian sites of La Gravette, in Dordogne (Moreau 2003; Goutas 2004); Geissenklösterle (Scheer 1995) and Mauern, in Germany; Mamutowa, in Poland (Otte 1981); Grub-Kranawetberg, in Austria (Antl 2005) or Arcy-sur-Cure, in Bourgogne (Girard and Baffier 2003), which also confirms that the Cro-Magnon pendants belong to the Gravettian. The choice of shell species and the perforation and manufacture techniques of these elements also validate this correlation (Taborin 1993).

The attribution of the Cro-Magnon sepulchral level to the Gravettian can thus be considered to be definitive, as it is based on a series of significant facts:

- the position of the skeletons under the vault of the shelter, at the top of the stratigraphic sequence and above the Aurignacian complex;

- the presence of Gravette points and a Bayac flechette in the ancient collections. The latter is a diagnostic element of the early Gravettian, particularly in level 5 of the Pataud rock shelter (Bricker 1995; Leoz 2007);

- similarities in the materials, shapes and manufacture techniques (and also undoubtedly the serial production mode) between the ivory ornaments from Cro-Magnon and those from level 5 of the Pataud rock shelter and also from other Gravettian sites in Europe;

- the $14 \mathrm{C}$ date of one of the littorinae associated with the skeletons.

The presence of ocher on the human bones and the probable association of a large flint blade with one of the skeletons (Lartet and Christy 1865-1875; Jones 1865-1875 - Plate $\mathrm{XX} \mathrm{n}^{\circ} 3$ ) also provide evidence for a Gravettian age for this level. Ocher and large flakes are some of the attributes associated with certain corpses in Italian Gravettian burials Mussi 1986; Henry- Gambier 2008; Onoratini et al. 2011). Furthermore, the date of the littorina from Cro-Magnon and the fact that the ivory pendants from Cro-Magnon are almost identical to those from level 5 from Pataud, but also to those from the early Gravettian from La Gravette, indicate that the Cro-Magnon human remains deposit can be attributed to an early phase of the Gravettian.

Lastly, at the time of the deposition of the human remains, the Cro-Magnon rock shelter was practically totally filled in. The height below the vault after the deposition of level $\mathrm{H}$ was no more than $1 \mathrm{~m}$ at the highest point (Lartet 1868). An occupation in the rock shelter would thus have been, at the least, very uncomfortable, if not impossible. There are thus two possibilities: either the early Gravettian groups occupied the zone in front of the shelter, or else the Cro-Magnon rock shelter was exclusively used for funerary purposes. It is clearly difficult to choose between these two hypotheses. During the early Gravettian, the Pataud rock shelter was a vast shelter, at least 8 to 10 $\mathrm{m}$ deep, with an estimated ceiling height of 2 to $2.5 \mathrm{~m}$ (Movius 1977), and was thus suitable for a durable installation, as shown by the very high density of archaeological material in level 5 and the multiple anthropogenic structures (mainly combustion) observed in the rear part of the shelter. This could indicate two synchronous functions for the vast, intensively occupied shelter (Pataud) and a practically fully filled in shelter (Cro-Magnon): Cro-Magnon may have been the funerary site for the Gravettians from level 5 in the Pataud rock shelter 9 . 
(1) have yielded a single individual deposit, the sites of Pavlov, Predmost, Dolni Vestonice, Krems, Cussac, Balzi Rossi, Pataud (level 2) and Cro-Magnon, either contained several deposits of human remains in what has been assimilated to a single cultural complex, or several individuals in a same tomb (Henry-Gambier, 2008; 2013). The presence of a relatively high number of deceased in a same site, with similar modalities, could provide a strong argument for long-term or repeated occupations by a same group. However, and in particular for the early discoveries, it is often difficult to estimate the duration and sequencing of the deposits: at Cro-Magnon, at least five individuals were deposited ${ }^{10}$ but the absence of information concerning anatomical connections at the time of discovery means that it is impossible to determine whether it is a plural (simultaneous deposits of corpses) or collective burial (deposits staggered throughout time). For the time being, no definitive answer exists to these questions, which are at the core of current research on the funerary behaviour of Gravettian populations in Europe. Moreover, this hypothesis opens up interesting perspectives in relation to the behaviour of Gravettian groups, with regard both to their organization of domestic space and their approach to death and the deceased. This dissociation has been attested at Cussac for the middle Gravettian (HenryGambier et al. in press) and is very likely at Vilhonneur in Charente for the early Gravettian (Henry- Gambier et al. 2007). In both these sites, the deceased were deposited in deep and decorated cavities which have not yielded any trace of habitation up until now. It could also be possible, although with less certitude, for the final Gravettian from the Pataud rock shelter (level 2) where the funerary deposits and the habitat appear to be separate (Henry-Gambier et al., 2013). 


\section{BIBLIOGRAPHY}

ANTL W. 2005 - L'industrie en os et en ivoire du site gravettien à Grub/kranawetberg orès de Stillfried. In : D. Vialou, J. Renault-Miskovsky, M. Patou-Mathis (dir.), Comportements des hommes du Paléolithique moyen et supérieur en Europe: territoire et milieu. Actes du colloque du GDR 1945 du CNRS, Paris 8-10 janvier 2003, Liège, ERAUL 111, p. 51-58.

AGSOUS S. 2008 - Stratigraphie et sédimentologie de l'abri Pataud (Les Eyzies de Tayac, Dordogne, France). Contribution à l'étude des paléoenvironnements des cultures du Paléolithique supérieur ancien du Périgord, Thèse de doctorat, Paris, Muséum national d'histoire naturelle, $241 \mathrm{p}$.

BOUCHUD J. 1966 - Remarques sur les fouilles de L. Lartet à l'abri Cro-Magnon (Dordogne), Bulletin de la Société d'Etudes et de Recherches Préhistoriques et Institut Pratique de Préhistoire et d'Art préhistorique, 24, Les Eyzies, 15, p. 28-36.

BOURLON M. 1907 - Un os utilisé présolutréen, Bulletin de la Société Préhistorique de France, 4, 5, p. 262-263.

BREUIL H. 1906 - Les gisements présolutréens du type d'Aurignac, CIAAP, Monaco, 1, p. 323-330.

BREUIL H. 1907 - La question aurignacienne. Etude critique et stratigraphie comparée, Revue Préhistorique, 2, p. 173-219.

BREUIL H. 1909 - L'Aurignacien présolutréen. Epilogue d'une controverse, Revue Préhistorique, 4, p. 229-248, 265-286.

BREUIL H. 1912 - Les subdivisions du Paléolithique supérieur et leur signification, CIAAP, Genève, 1, p. $165-238$

BREUIL H. 1960 - Ma vie en Périgord, 1897, 1959, Bullletin de la Société Historique et Archéologique du Périgord, 37, p. 114-131.

BRICKER H. M. 1995 - Le Paléolithique supérieur de l'abri Pataud (Dordogne) : les fouilles de H. L. Movius Jr., Documents d'archéologie française, 50, Paris : éditions de la maison des sciences de l'homme, $328 \mathrm{p}$.

CARTAILHAC E. 1872 - Compte rendu de l'excursion aux Eyzies du 8 septembre 1872, Association française pour l'Avancement des sciences, Bordeaux, p. 1278-1282.

CHIOTTI L. 2005 - Les industries lithiques aurignaciennes de l'abri Pataud, Dordogne, France. Les fouilles de Hallam L. Movius Jr. Oxford : Archaeopress, 349 p. (BAR International Series, 1392).

CONARD N. J., BOLUS M. 2003 - Radiocarbon dating the appearance of modern humans and timing of cultural innovations in Europe: new results and new challenges, Journal of Human Evolution, 44, p. 331-371.

DANCE P. 1975 - The Molluscan fauna. in: Movius H. L. (dir.), Excavation of the abri Pataud, Les Eyzies (Dordogne): Contributors. Cambridge, Massachusetts: Peabody Museum, Harvard University, p. 154-159 (American School of Prehistoric Research, bull. 30).

DELLUC B, DELLUC G. 1986 - Un bouquetin sculpté de style solutréen dans la cave troglodytique Pataud (Les Eyzies, Dordogne), L’Anthropologie, 90,4, p. 603-612.

DELLUC B. ET DELLUC G. 2013 - Les squelettes de l'abri de Cro-Magnon. Datation et pathologie. Evolution des idées. Bulletin de la Société Historique et Archéologique du Périgord, CXL, p.

243-274 
FÉAUX M. 1902 - Un os gravé à Cro-Magnon. Epoque Magdalénienne, Bulletin de la Société historique et archéologique du Périgord, 29, p. 415-418.

FISHER P. 1872 - Sur les coquilles récentes et fossiles trouvées dans les cavernes du Midi de La France et de la Ligurie, Matériaux pour l'Histoire primitive et naturelle de l'homme, 7, p. 482.

FU Q., MITTNIK A., JOHNSON PH. L.P.,BOS K., LARI M., BOLLONGINO R., SUN C., GIEMSCH L., SCHMITZ R., BURGER J., RONCHITELLI AM.,MARTINI F., CREMONESI R. G., SVOBODA J.,BAUER P., CARAMELLI D., CASTELLANO S., REICH D., PÄBÖ S., KRAUSE J. 2013 - A Revised Timescale for Human Evolution Based on Ancient Mitochondrial Genomes, Current Biology, 23, p. 553 -559.

GIRARD M., BAFFIER D. 2003 - Découverte d'une pendeloque en ivoire du début du paléolithique supérieur à la Grande grotte d'Arcy-sur-Cure (Yonne), Revue archéologique de l'Est, 52, p. 343-350.

GIRAUX L. 1907 - Ossements utilisés de Cro-Magnon, Bulletin de la Société préhistorique de France, 4, 5, p. 264-268.

GIROD P. 1906 - Les stations de l'Âge du renne dans les vallées de la Vézère et de la Corrèze: stations solutréenne et aurignaciennes, Paris, J. B. Baillière et fils.

GIROD P. 1907 - Aurignacien et pré-solutréen, Congrès Préhistorique de France, Autun, 1907, 1, p. 174-178.

GOUTAS N. 2004 - Caractérisation et évolution du Gravettien en France par l'approche technoéconomique des industries en matières dures animales (étude de six gisements du Sud-ouest), Thèse de doctorat. Paris : Université de Paris I - Panthéon-Sorbonne, 2 vol., 675 p.

GOUTAS N. 2005 - Etude de la parure en coquillages, sur dents animales et en ivoire des niveaux gravettiens du gisement de la Gravette (Dordogne) : charge identitaire et souplesse des normes techniques, Antiquités Nationales, p. 39-51.

HAHN J. 1995 - Les ivoires en Allemagne, débitage, façonnage et utilisation au Paléolithique supérieur. In : Hahn J., Menu M., Taborin Y., Walter P., Widemann F. (éds.), Le travail et l'usage de l'ivoire au Paléolithique supérieur, actes de la table ronde de Ravello, Rome, 29-31 mai 1992, p. 115-132.

HENRY-GAMBIER D. 2002 - Les fossiles de Cro-Magnon (Les-Eyzies- de-Tayac, Dordogne): Nouvelles données sur leur position chronologique et leur attribution culturelle, Bulletins et Mémoires de la Société d'Anthropologie de Paris, 14, 1-2, p. 89-112.

HENRY-GAMBIER D. 2008 - Pratiques funéraires et comportement des populations gravettiennes en Europe : bilan des données et interprétations. In : Le Gravettien : entités régionales d'une paléoculture européenne, actes de la table ronde des Eyzies-de-Tayac (juillet 2004), Paléo 20, p. $399-438$

HENRY-GAMBIER D. 2011 - Vestiges humains de l'abri Cro-Magnon (Les-Eyzies-de-Tayac Dordogne) : Tentative d'individualisation des os de l'adulte CM1. Rapport remis à L. Isnard, conservateur du patrimoine dans le cadre de la mission effectuée au Muséum national d'Histoire naturelle (Paris), Laboratoire d'Anthropologie, Musée de l'Homme du 2 au 5 novembre 2010 et du 10 au 12 janvier 2011. Document inédit et non utilisable sans l'accord écrit de l'auteur (15 p.).

HENRY-GAMBIER D. 2013 - Les populations gravettiennes. Biologie et comportements funéraires, In : M. Otte (Ed.), Les Gravettiens, p. 307-330.

HENRY-GAMBIER D., BRUZEK J., SCHMITT A., HOUËT F., MURAIL P. 2005 - Révision du sexe et de l'âge au décès des fossiles de Cro-Magnon (Dordogne, France) à partir de l'os coxal. Comptes Rendus Palevol, 5, p. 735-741. 
HENRY-GAMBIER D., BEAUVAL C., AIRVAUX J., AUJOULAT N., BARATIN J.F., BUISSON-CATIL J. 2007 - New hominid remains associated with gravettian parietal art (Les Garennes, Vilhonneur, France), Journal of Human Evolution, 53, p. 747 - 750.

HENRY-GAMBIER D., VILLOTTE S., BEAUVAL C., BRUZEK J., GRIMAUD-HERVÉ D. 2013 - Les vestiges humains : un assemblage original. In : Nespoulet R., Chiotti L., Henry-Gambier D. (dirs), Le Gravettien final de l'abri Pataud (Dordogne, France). Fouilles et études 2005-2009. Oxford : Archaeopress (BAR International Series, 2458), p. 135-177.

HENRY-GAMBIER D., COURTAUD P., DUDAY H., DUTAILLY B., VILLOTTE S., DEGUILLOUX M.-F., PEMONGE M.-H., AUJOULAT N., DELLUC M., FOURMENT N., JAUBERT J. sous presse - Grotte de Cussac (Le Buisson-de-Cadouin) : un exemple de comportement original pour le Gravettien. In : actes du XXVIIème Congrès préhistorique de France. Bordeaux-Les Eyzies-de-Tayac, (31 mai - 5 juin 2010) Société préhistorique française.

HIGHAM T., JACOBI R., BASELL L., BRONK RAMSEY C., CHIOTTI L., NESPOULET R. 2011 - Precision dating of the Palaeolithic: A new radiocarbon chronology for the Abri Pataud (France), a key Aurignacian sequence, Journal of Human Evolution, 61, 5, p. 549-563.

JAUBERT DR. 1868 - Compte rendu de la communication du Dr. Galy sur la découverte des fossiles de Cro-Magnon à la Société médicale d'observation de la Dordogne (2 avril 1868), Société agricole et littéraire de la Dordogne, 29, p. 691.

JONES T. R. 1865-1875 - A propos du matériel archéologique découvert à Cro-Magnon, In : E. Lartet et H. Christy (dir.) Reliquiae Aquitanicae: being Contributions to Anthropology and Palaeontology of Périgord and the Adjoining Provinces of Southern France, 2, p. 82-88, 92-94, Thomas Rupert Jones (ed.), 1865-1875. Londres : Williams and Norgate (H. Baillière), 1875 (Ed. originale et Traduction J.P. Chadelle).

JÖRIS O., STREET M. 2008 - At the end of the ${ }^{14} \mathrm{C}$ time scale: the Middle to Upper Palaeolithic record of Western Eurasia, Journal of Human Evolution, 55, p. 782-802.

LARTET E. 1861 - Nouvelles recherches sur la coexistence de l'Homme et des grands mammifères fossiles réputés caractéristiques de la dernière période géologique. I, station et sépulture d'Aurignac, II, les grottes de Massat et la caverne de Savigné, Annales des Sciences naturelles. Zoologie et Paléontologie, 15, p. 177-253.

LARTET L. 1868 - Une sépulture des troglodytes du Périgord, Bulletins de la Société d'Anthropologie de Paris, 3, p. 335-349.

LARTET E., CHRISTY H. 1865-1875 - Reliquiae aquitanicae: being contribution to the Archaeology and Paleontology of Perigord and the adjoining provinces of Southern France. Thomas Rupert Jones (ed.), 1865-1875. Londres : Williams and Norgate (H. Baillière), 1875 (Ed. originale et Traduction J.P. Chadelle).

LEGOUX P. 1975 - Présentation des Dents des Restes Humains de L'Abri Pataud. In : Movius H.L. (ed.), Excavation of the abri Pataud, Les Eyzies (Dordogne): Contributors. Cambridge,Massachusetts: Peabody Museum, Harvard University, p. 262-305 (American School of Prehistoric Research, bull. 30).

LENOBLE A., AGSOUS S. 2012 - Abri Pataud - sédimentogenèse, paléopédologie, chronologie des dépôts. In : P. Bertran, A. Lenoble (dir.) Quaternaire continental d'Aquitaine :Un point sur les travaux récents. Livret-Guide Excursion AFEQ - ASF en Aquitaine, 30 mai -1 juin 2012, p.45-57. 
LEOZ L. E. 2007 - Les industries lithiques du Gravettien ancien de l'abri Pataud, Les -Eyzies-deTayac (Dordogne) : étude typologique et technologique du niveau 5. Thèse de doctorat, Muséum national d'histoire naturelle, Paris, $233 \mathrm{p}$.

MASSÉNAT E. 1869 - Pointe de Lance à Cro-Magnon, Matériaux pour l'Histoire primitive et naturelle de l'homme, p. 357.

MASSÉNAT E. 1877 - Les fouilles des stations des bords de la Vézère et les œuvres d'art de Laugerie-Basse, Matériaux pour l'Histoire primitive et naturelle de l'homme, 8, p. 1-3.

MASSÉNAT E., GIROD P. 1893 - Nouvelles fouilles préhistoriques dans la vallée de la Vézère, Association française pour l'Avancement des sciences, Besançon, p. 739-749.

MELLARS P. 2004 - Neanderthals and the modern human colonization of Europe, Nature, 432, 7016, p. 461-465.

MOREAU L. 2003 - Les éléments de parure au Paléolithique supérieur en Belgique, L'Anthropologie, 107, p. 603-614.

MOVIUS H. L. 1969 - The abri of Cro-Magnon, Les Eyzies (Dordogne) and the probable age of the Contained Burials on the basis of the evidence of the nearby abri Pataud, Anuario de Estudios Atlanticos, 15, p. 323-344.

MOVIUS H. L. 1975 - Excavation of the abri Pataud, Les Eyzies (Dordogne): Contributors. Cambridge, Massachusetts: Peabody Museum, Harvard University, American School of Prehistoric Research, 30, 305 p.

MOVIUS H. L. 1977 - Excavation of the abri Pataud, Les Eyzies (Dordogne): Stratigraphy. Cambridge, Massachusetts: Peabody Museum, Harvard University, 167 p. (American School of Prehistoric Research, 31).

MUSSI M. 1986 - Italian Palaeolithic and Mesolithic Burials, Human Evolution, 1, 6, p. 545-556.

NESPOULET R. 1993 - Le Solutréen de l'abri Pataud. Les Eyzies de Tayac, Bulletin de la Société Historique et Archéologique du Périgord, 122, p. 409-518.

NESPOULET R., CHIOTTI L., HENRY-GAMBIER D., AGSOUS S., LENOBLE A., MORALA A., GUILLERMIN P., VERCOUTÈRE C. 2008 - L'occupation humaine de l'abri Pataud (Les Eyzies-deTayac, Dordogne) il y a 22000 ans : problématique et résultats préliminaires des fouilles du niveau 2. In : Jaubert J. (dir.), Les sociétés paléolithiques d'un grand Sud-Ouest : nouveaux gisements, nouvelles méthodes, nouveaux résultats, actes des journées de la SPF, Bordeaux (24-25 novembre 2006). Paris : Société préhistorique française, p. 325-334 (Mémoire de la SPF, XLVII).

ONORATINI G., SIMON P., NEGRINO F., CAUCHE D., MOULLÉ P.E., ARELLANO A., BORGIA V., VOYTEK B., ARRIGHI S. 2011 - Du Sud de la montagne de Lure aux sépultures de Grimaldi : le silex zoné stampien dit « du Largue », Bull. Mus. Anthropo. préhist. Monaco, 51, p. 52-74.

OTTE M. 1981- Le Gravettien en Europe centrale, 2 vol. de Tempel, Bruges Disserationes archaelogicae Gandenses.

PEYRONY D. 1907 - Nouvelles recherches à Cro-Magnon, Congrès Préhistorique de France, Autun, 1907,1, p. 182-185.

PITTARD E. 1962 - Une gravure de Cro-Magnon (Dordogne) exilée à Neuchâtel (Suisse), Bulletin de la Société d'Etudes et de Recherches préhistoriques et Institut Pratique de Préhistoire et d'Art préhistorique, 24, Les Eyzies, 12, p. 36-39.

REIMER P. J., BAILLIE M. G. L., BARD E., BAYLISS A., BECK J. W., BLACKWELL P. G., BRONK RAMSEY C., BUCK C. E., BURR G. S., EDWARDS R. L., FRIEDRICH M., GROOTES P. M., GUILDERSON T. P., 
HAJDAS I., HEATON T. J., HOGG A. G., HUGHEN K. A., KAISER K. F., KROMER B., MCCORMAC F. G., MANNING S. W., REIMER R. W., RICHARDS D. A., SOUTHON J. R., TALAMO S., TURNEY C. S. M., VAN DER PLICHT J., WEYHENMEYER C. E. 2009 - IntCal09 and Marine09 Radiocarbon Age Calibration Curves, 0-50,000 Years cal BP. Radiocarbon, 51, 4, p. 1111-1150.

RIVIÈRE E. 1894 - Nouvelles recherches anthropologiques et paléontologiques dans la Dordogne, Association française pour l'avancement des sciences, 23ème session, Caen, 1894, seconde partie, notes et mémoires, p. 709-722.

RIVIÈRE E. 1897 - Nouvelles recherches à Cro-Magnon, Bulletins de la Société d'Anthropologie de Paris, 8, p. 503-508.

RIVIÈRE E. 1905 - Les rabots magdaléniens en silex de la Dordogne, Bulletin de la Société préhistorique de France, 8, p. 270-275.

SCHEER A. 1995 - Pendeloques en ivoire durant le Gravettien en Allemagne du sud - Un indice chronologique et social ? In: Hahn J., Menu M., Taborin Y., Walter Ph., Widemann F. (eds), Le travail et l'usage de l'ivoire au Paléolithique supérieur, Ravello, 29-31 mai 1992. Istituto Poligrafico E Zecca Dello Stato, Libreria Della Stato, p. 137-172.

SMITH P. E. 1966 - Le Solutréen en France, Publication de l'Institut du Quaternaire, Université de Bordeaux.

SONNEVILLE-BORDES D. (de) 1959 - Position stratigraphique et chronologique relative des restes humains du Paléolithique supérieur entre Loire et Pyrénées, Annales de Paléontologie, 45, p. 19-51.

SONNEVILLE-BORDES D. (de) 1960 - Le Paléolithique supérieur en Périgord, Bordeaux, Delmas.

SZMIDT C., NORMAND C., BURR G., HODGIND G., LAMOTTA S. 2010 - AMS ${ }^{14} C$ dating the Protoaurignacian/Early Aurignacian of Isturitz, France: implications for Neanderthal-modern human interaction and the timing of technical and cultural innovations in Europe. Journal of Archaeological Science, 37, p. 758-768.

TABORIN Y. 1993 - La parure en coquillage au Paléolithique, Gallia Préhistoire, 29ème supplément, CNRS Paris.

VERCOUTÈRE C. 2004 - Utilisation de l'animal comme ressource de matières premières nonalimentaires : industrie osseuse et parure. Exemple de l'abri Pataud (Dordogne, France). Thèse Muséum national d'Histoire naturelle, département de Préhistoire, Institut de Paléontologie Humaine, $261 \mathrm{p}$.

VERCOUTÈRE C., GIACOBINI G., PATOU-MATHIS M. 2008 - Une dent humaine perforée découverte en contexte Gravettien ancien à l'abri Pataud (Dordogne, France), L'Anthropologie, 112, 2, p. 273-283.

VILLOTTE S. 2009 - Enthésopathies et activités des hommes préhistoriques : recherche méthodologique et application aux fossiles européens du Paléolithique supérieur et du Mésolithique. Oxford : Archaeopress, 206 p. (BAR International Series, 1992).

VILLOTTE S. 2011 - Les comportements au Gravettien : apport des « marqueurs osseux d'activité ». In : Goutas, N., Klaric, L., Pesesse, D. et Guillermin, P. (Eds.), À la recherche des identités gravettiennes : actualités, questionnements et perspectives, Actes de la table ronde sur le Gravettien en France et dans les pays limitrophes, Mémoires de la Société Préhistorique Française, 52, p. 217-224.

VILLOTTE S., BRUZEK J. ET HENRY-GAMBIER D. 2011 - Caractéristiques biologiques des sujets adultes gravettiens : révision de l'âge au décès et du sexe. In Goutas, N., Klaric, L., Pesesse, D. et 
Guillermin, P. (Eds.), À la recherche des identités gravettiennes : actualités, questionnements et perspectives, Actes de la table ronde sur le Gravettien en France et dans les pays limitrophes, Mémoires de la Société Préhistorique Française, 52, p. 209-216.

ZILHAO J., D'ERRICO F. 1999 - The chronology and taphonomy of the earliest Aurignacian and its implications for the understanding of Neanderthal extinction, Journal of World Prehistory N-Y, 13, p. 1-68.

ZILHAO J., D'ERRICO F. 2003 - The chronology of the Aurignacian and transitional technocomplexes: where do we stand? In : J. Zilhão et F. d'Errico (dir.) The chronology of the Aurignacian and transitional technocomplexes: dating, stratigraphies and cultural implications, p.313-349. Lisbon: Instituto Portugues de Arqueologia. (Trabalhos de Arqueologia, 33).

\section{NOTES}

4. Calibrated date, CALIB programme version 6.0 according to intcal 09.14C (Reimer et al. 2009). Probability $=1$.

5. Maximum limit of the 2 sigma dating interval.

6. A recent palaeogenomic article (Fu et al., 2013) published an age of $690+/-39$ BP OxA-V-2321 with the reference Cro-Magnon 1. This date was not carried out on the Cro-Magnon 1 specimen but on a sample taken from a bone from a complex (MNHN 2330 - 25290 and 25 291) stocked with eponymous fossils with inventory numbers ranging from 4252 to 4345 . No context (inventor, exact localization, stratigraphic origin) is available for the bones from this intrusive complex in the collection. The bones bear a totally different patina to that of the bones from the Palaeolithic complex and no traces of ocher have been observed, whereas all the bones discovered in 1868 present ocher stains. It is important to recall that the many attempts to directly date the Cro-Magnon fossils found in 1868 (two by the Gif-sur-Yvette laboratory, twelve by Oxford...) showed that the collagen was not preserved. This episode attempts to cast doubt on the age of the skeletons discovered in 1868 and illustrates the inacceptable practice of taking samples without an anthropologist who knows the collection and its history. The quest for a scoop undoubtedly justifies some of these methods.

7. During the course of the private restructuring of the Cro-Magnon site, remnants of archaeological levels were discovered adhering to the walls of the rock shelter. It is unfortunate that no archaeological operation based on scientific objectives related to current research on the Gravettian and the Aurignacian was organized at this time. This operation should have included the topographic recording of the site and its environment, the sieving of old and recent spoil, research into possible remnants of in situ levels and the study of the material.

8. Although the engraved ibex on the vault of the Movius rock shelter in the present day site museum is Solutrean (Delluc and Delluc 1986), this part of the site was not entirely filled in during the Solutrean.

9. Level 5 from the Pataud rock shelter yielded three human teeth including one perforated tooth (Legoux 1975; Vercoutère et al. 2008). Two of these are milk teeth.

10. Recent and ongoing studies (ex.Villotte 2009, 2011; Villotte et al. 2011; Henry-Gambier et al. 2005) validate an MNI of four adults and one child. The adults are represented by one hundred and twenty remains (whole or fragmentary bones), which correspond to a very poor rate of skeletal representation (Henry-Gambier 2011). The distribution of the bones per specimen (CM 1, $2,3,4)$ is currently being reviewed. For example, in the current state of research, twenty bones at the most can be associated with the skull CM1 nº 4253 (Henry-Gambier 2011). 


\section{ABSTRACTS}

In 2002, the ${ }^{14} \mathrm{C}$ AMS dating of a perforated shell (Littorina littorea) associated with the skeletons discovered in 1868 (Lartet 1868) in the Cro-Magnon rock shelter (Beta 157439: $27680 \pm 270 \mathrm{BP}$, or 31,324-32 666 cal BP), excluded their attribution to the Early Aurignacian and suggested that they were deposited during an early phase of the Gravettian. A revision of the Gravettian sequence of the Pataud rock shelter, located less than 300 meters downstream on the same bank of the Vézère River, along with new ${ }^{14} \mathrm{C}$ dates of this sequence and a study of the pendants from layer 5 , now enable us to confirm the attribution of the fossils from Cro-Magnon to the Early Gravettian.

En 2002, la datation ${ }^{14} \mathrm{C}$ par SMA d'un coquillage percé (Littorina littorea) associé aux squelettes découverts en 1868 dans l'abri Cro-Magnon conduisait à rajeunir ces fossiles, attribués depuis leur découverte à l'Aurignacien ancien. Cette date indiquait que le sommet de la séquence archéologique de l'abri Cro-Magnon comportait des niveaux Aurignacien récent et/ou Gravettien. Cette date, Beta 157439: $27680 \pm 270$ BP (31 324-32 666 cal BP), est comprise dans un intervalle coïncidant soit avec une phase récente de l'Aurignacien soit avec le Gravettien ancien (Henry-Gambier 2002). Un réexamen de la séquence gravettienne de l'abri Pataud, situé à moins de $300 \mathrm{~m}$ en aval de l'abri Cro-Magnon sur la même rive de la Vézère, de ses nouvelles datations ${ }^{14} \mathrm{C}$ ainsi que de ses parures gravettiennes permet aujourd'hui d'asseoir solidement l'appartenance des fossiles de Cro-Magnon au Gravettien ancien.

\section{INDEX}

Keywords: Cro-Magnon, Pataud, Dordogne, Homo Sapiens Sapiens, Gravettian, Burial, Pendant

Mots-clés: Cro-Magnon, Pataud, Dordogne, Homo Sapiens Sapiens, Gravettien, sépulture, parure

\section{AUTHORS}

\section{DOMINIQUE HENRY-GAMBIER}

Université Bordeaux1, UMR PACEA - 5199 - CNRS - A, B8- Avenue des Facultés, FR-33405 Talence d.gambier@pacea.u-bordeaux1.fr

\section{ROLAND NESPOULET}

Département de Préhistoire, Muséum national d'histoire naturelle, UMR 7194 du CNRS, Bâtiment de Géologie, 43 rue Buffon, FR-75005 Paris - roland.nespoulet@mnhn.fr

\section{LAURENT CHIOTTI}

Département de Préhistoire, Muséum national d'histoire naturelle, UMR 7194 du CNRS, Musée de l'abri Pataud, 20, rue du Moyen-Âge, FR-24620 Les Eyzies-de-Tayac - lchiotti@mnhn.fr 